\title{
The Historical-Cultural Value of the Juvenile Collection: The McLaren Collection at the University of Melbourne and its Girls' Books
}

\author{
Bronwyn Margaret Lowe
}

The University of Melbourne

In the last fifty years special collections of children's books have received increasing attention from scholars who have started to realise the value of these books as literary and historical documents. Collections of children's books in academic libraries across the world ${ }^{1}$ provide a sampling of the types of books children would have read in a particular period or country. The McLaren Collection of children's books, held in the Baillieu Library at the University of Melbourne, is valuable for its varied range of children's books. This important collection was assembled by Ian McLaren (19122000), a chartered accountant and Member of Parliament who also took a particular interest in book collecting during his long and varied career. His collection comprises over 50,000 items on Australian politics, history and literature. While the majority of his collection is held by the Baillieu Library, the National Library of Australia holds his collection of local histories, church histories, business histories and organizational histories. Approximately 5000 books in the McLaren collection were classified by him as children's books, and they are all held at the Baillieu Library.

This article will consider the importance of collections of children's books in the university library generally, and why they can be of use to scholars. It will then address the McLaren collection specifically, creating a small sampling of girls' books from the collection to discuss the sort of books Australian girls would have been reading in the first half of the twentieth century, and the views and values that authors of this period wanted to pass on to girls. These will be used to address a broader discussion of the historical-cultural value of girls' books in the collection.

\section{Value of Children's Book Collections}

Ian McLaren began his collection in 1946, in a response to his interest in bibliography, and continued collecting into the 1960s (NLA). Although he collected a wide range of Australian books and ephemera, McLaren's collection of children's books is particularly valuable to the historian of reading (such as myself), as it is ambitious in its exceptionally broad focus. It contains novels, school books, annuals and comics from over a 100-year period. The collection, including valuable first editions - such as books by Norman Lindsay and Ethel Turner-also holds books that did not enjoy great popularity or multiple print-runs at their time of publication. McLaren's vast collection 
of children's books has particular value because for many years Australian children's books were considered unworthy of collection by most Australian collectors. This phenomenon was noted by the small number of collectors who saw the value in this genre, such as Ken Pound, who collected children's books across a twenty-year period. The collection was then acquired by the State Library of Victoria. Discussing this collection, Clare Bradford states that one motivation for Pound's collecting 'was his sense (encapsulated in the question, "Why don't you collect something worthwhile?") that children's books were treated by many dealers and collectors as unworthy of serious attention and that Australian books and illustrators were regarded as less significant, by reason of their colonial origins, than their British counterparts' (Bradford 1998, p.328). This comment draws attention to the dual reason for the neglect of Australian children's books in collections until recently: children's books have been regarded as unworthy of attention in comparison with adult's books, and Australian books have been considered less significant than similar British books.

Nonetheless, collections such as the Pound Collection at the State Library of Victoria and the McLaren collection at the University of Melbourne showcase the richness of the many different types of children's books that were circulated in Australia. Both of these collections hold books that have fallen out of print, popular memory and reading practice. In some cases, copies of books held in these collections can be almost impossible to find elsewhere (see O'Neil 1994, p.6-9), because many had very limited print-runs. Yet librarians in Special Collections at the Baillieu Library say that the McLaren collection is used by only a small number of readers, and the children's books by fewer still (pers. comm.). This has led some to question the purpose of holding collections of children's books in the academic library. Thankfully today, their importance is starting to be understood. Alice Crosetto and Mark Horan state that 'the question of the juvenile collection in an academic library mirrors the value and acceptance of children's literature in the canon of academic literature' (Crosetto \& Horan 2007, p.101). As the study of children's literature has gained acceptance and growing popularity, appearing in more mainstream journals and taught in more universities, so has the presence of juvenile collections in libraries been accepted.

Apart from containing specific books that might be difficult to obtain elsewhere, the children's book collection also has value as a whole, in that it can act as a reminder to scholars of the existence of children as a group of readers. Kenneth Kidd explains this by stating that, for collections of children's books specifically, 'the historical-cultural value of the archive is collective or cumulative; individual titles generally matter less than the overall collection. Individual titles are not necessarily canonical or literary; most are neither' (Kidd 2011, p.8). In this way the importance to libraries of having a collection of children's literature outweighs the value of any one book that is held. Kidd here uses the word 'archive' in an unusual way, as the word is normally used to describe collections of papers and manuscripts rather than collections of entire books. Discussing his work in the Baldwin Library of Historical Children's Literature, Kidd uses the word 'archive' as a descriptor because the Baldwin Library 'is non-circulating and because its materials no longer circulate in the wider culture and in some cases are the only surviving copies' (Kidd 2011, p.3). This is certainly the case for the McLaren collection, and so in this way this collection could also be 
described as an archive. This could remind historians of the historical-cultural value of such a collection.

Although it is important to have an archive that includes lesser known and out-of-print books, the purpose and scholarly value of such a collection must be established in order to secure its place in the academic library. Crosetto and Horan state that 'the preservation of children's literature of historical interest may have been one of the traditionally acceptable reasons for maintaining such a collection at the academic level; but now the potential use of this literature across the academic curriculum is untapped' (Crosetto \& Horan 2007, p.105). Although we have seen that an archive such as the McLaren collection has value in itself, its potential for use in various avenues of further study has not yet been fully realised. While Crosetto and Horan's statement is directed towards the use of juvenile literature in the general collections of academic libraries, this argument also has merit for books held in special collections that no longer circulate. Indeed, the inclusion of books that no longer enjoy a prominent place in the academic curriculum might remind students and scholars of the value of these texts. Crosetto and Horan argue for children's books as documents of human experience, saying that the books 'are objects that persist as a force throughout our lives in numerous formats and iterations... This very fact demands their existence in academic disciplines not only in Education but in any discipline that studies the human condition' (Crosetto \& Horan 2007, p.106). The importance of children's books as documents of the 'human condition' should not be underestimated. Indeed, children's books that might be deemed by today's society as excessively racist or sexist can reveal more of a society's views and values than many other genres of literature. Many scholars have already discussed the way children's books can be read as a strong reflection of society's values: Michael Paris (2004), for example, discusses the way children's authors wrote especially patriotically in wartime Britain, so that patriotic values could be instilled in children growing up during that time. As such, children's books provide us with clear ideas of the views and values that children's authors most wanted to instil in their readers. Examples of these values can be seen in the girls' books discussed later on in the article.

\section{Issues in Children's Book Collections}

While the importance of the juvenile collection as an archive is no longer disputed, difficulties still arise when exploring these collections. Beverley Lyons Clark, points out the disconnection between the scholars who use the children's book archive for research and the librarians who maintain it, stating that, in children's literature criticism, 'the work of librarians is usually ignored by academic critics' (Lyons Clark 2003, p.75). She illustrates this by discussing the reluctance of the Modern Language Association to accept journals such as the School Library Journal to be included in their bibliographies of academic journals. Lyons Clark also comments on the importance of the bibliographies of juvenile collections that librarians create: 'I suspect it would be hard to find a field more heavily "bibliographied" than children's literature. But neither such collections nor bibliographies carry great prestige with literary critics' (Lyons Clark 2003, p.75). While these bibliographies are indeed of infinite importance to literary scholars and critics (the University of Melbourne's bibliography of the children's books of the McLaren collection was integral to this article), librarians' ability to obtain such books and then to preserve the quality of these books over 
decades is also invaluable, especially when it is understood that most of the physical work in the ongoing maintenance of juvenile collections can only be completed by librarians.

Patricia A. Morris, the faculty director of the Preservation Department of the University of Colorado libraries, discusses some of the particular problems that will continue to arise for librarians when attempting to maintain collections of children's literature. She states that:

Children's books are still published as cheaply as possible for the use of children, who will damage them or lose interest in them; as a result, most copies of children's titles will be damaged beyond repair or simply discarded... academic libraries, having acquired a specific title in children's literature, will have to retain it for the indefinite future. Once that volume has suffered too much damage or is lost, it may be too costly or even impossible to replace.

(Morris 2010, p.101)

The librarian thus has the responsibility for the indefinite maintenance of books that may not exist anywhere else in the future. Morris also discusses the condition in which children's books are found in special collections. She argues that as special collections are generally made up of the private collections of people who mostly obtained pre-used books from second-hand book shops or auctions, these books also have a higher degree of damage. This damage has generally been caused by the previous owner, who might have scribbled or signed their name on the front page. Children's books tend to have more damage overall, as they have been more roughly handled by their owners (Morris 2010). While this type of damage generally lowers the monetary value of such texts, it adds value for historians of reading as defacements can show the scholar, for example, how the childreader obtained the book and even sometimes what they thought of it. In this way, texts held in special collections have specific value to scholars of reading history.

\section{The McLaren Collection of Children's Books and Gender Bias}

The McLaren collection at the University of Melbourne library contains books from the childhoods of many different Australians, and here I discuss some particular items that may have played a role in the childhood and adolescence of Australian girls specifically. The collection holds many items of girls' literature, including ninety books by the Turner circle - comprising Ethel and Lilian Turner and Jean Curlewis - and sixty books written by Mary Grant Bruce and her husband George Bruce (University of Melbourne 1999). It also includes Australian girls' books from authors such as Louise and Amy Mack, Lilian Pyke and Constance Mackness. It is clear, however, when looking through the collection that boys' stories exist in greater volumes than girls' stories. The collection's bibliographers, Terrence O'Neil and Stella Lees, are correct in saying that 'as the twentieth century advanced the lines between girls' and boys' books became more blurred' (University of Melbourne 1999), showing the growing trend throughout the century of books being marketed towards both girls and boys. Yet this does not hide the fact that boys' books, especially early twentieth century boys' books, are more strongly represented in the collection than girls' books of a similar period.

There could be many reasons for this. One of the more obvious reasons: Ian McLaren was himself once a boy, thus possibly found boys' books more appealing than girls' books when he collected 
them, perhaps subconsciously influenced by the image of Australian childhood as he experienced it. Another reason could be the status of girls' books, which were considered by many members of the public to be 'lower fiction'. Kimberley Reynolds gives an account of the esteem accorded to different genres of children's books: 'high fiction consists of those works recognized as having literary merit, among which boys' adventure and school stories, depictions of bourgeois family life, and a hybrid of fantasy and riddle à la Alice in Wonderland or Lear's nonsense books predominate. Low fiction includes those works denied any literary merit, notably girls' stories and "bloods" or comics' (Reynolds 1990, p.xvi). She goes on to say that 'while the division of boys' fiction into "high" and "low" mainly reflected the class of those for whom it was intended, most fiction specifically written for and read by girls was categorised as low regardless of the class of the audience' (Reynolds 1990, pp.xvii-xviii). Although McLaren consciously collected books that would have been considered both high and low, including the annuals and comics which were generally considered to be a form of low culture, perhaps this idea of girls' fiction as particularly low fiction affected his collecting.

The weighting of the collection towards boys' books is more surprising when it is understood that girls read more books than boys (Lyons \& Taksa 1990). Consequently, McLaren's collection of girls' books represents a smaller overall sample of what girls would have been reading in their youth. In a research paper on the reading, film and radio tastes of high school boys and girls in New Zealand, first published in 1947, W.J. Scott explained it this way: 'girls still spend more time in the home than boys and have greater opportunities for reading. Fewer of the girls, too, need to study so hard as the majority of the boys, because they do not so often have to prepare for a career for which a highly specialized education is required' (Scott 1977, p.56). In his acceptance of girls' limited career prospects in New Zealand at the time, Scott shows another way in which girls were held in lower esteem. Kate Darian-Smith describes a similar situation in Australia, stating that 'boys stayed at school longer and continued to tertiary levels more frequently than girls, because of the general expectation that males and not females would be breadwinners' (Darian Smith 2009, p.131). In the year 1950, statistics show 2,156 boys in New South Wales enrolling in year 11, and 1,639 girls (Enrolment Rates 2012), while in 1952, under twenty percent of those receiving tertiary education in Australia were female (Booth \& Kee 2009, p.6). This indicates the educational disadvantage experienced by girls at this time. Despite the fact that girls were generally expected to help more around the house, these statistics do show how girls could have been seen to have more time for reading as they were not in school in as greater numbers.

Scott's paper also shows the way in which girls' literature was marginalised. Defining the nature of a 'good book', he says that 'to be good a book must deal with the real world of men and things... the experience of reading such a book will increase the reader's knowledge of himself, others, and the world he lives in' (Scott 1977, p.29). Although in this instance Scott might be using an accepted form of the word 'man' to mean 'people', it nonetheless gives the impression that only boys' books were considered to be the 'good books'. As we have seen that retention rates for girls in high school and tertiary education at this time were low, perhaps only boys were considered to have the education levels required to read 'good books'. Many girls did however read boys' books, even 
though these books were not marketed to them, especially if they had brothers from whom they could easily borrow books.

This marginalisation of girls' books both in their representation in the McLaren collection and in W.J. Scott's opinion brings to mind Ken Pound's view, mentioned at the beginning of this article. Pound, an avid collector of children's books, believed that Australian children's books were considered to be unworthy of attention by collectors because they were written for children and because they were considered 'colonial' and unsophisticated in their tastes in comparison with English books of a similar genre. If this is the case, then Australian girls' books must be considered to have been even less worthy of attention, being considered neither 'good books' nor 'high fiction'. It is therefore important to explore some of these girls' books in McLaren's collection, to find out what was considered to be appropriate for Australian girls and what they might tell us about girls' 'human experience' as Crosetto and Horan discussed it.

\section{Examples of Girls' Books from the Collection}

While there are many books in the collection that could be considered for the purpose of compiling a sample of what girls would have read in the first half of the twentieth century, this article will consider a few examples published between 1894 and 1942. It will discuss two books published by Australian authors utilising the popular Australian plotline of the 'cousin from town'. It will then consider two books published by English authors which would have been read by Australian girls, and will finally explore the genre of 'instruction' literature in a book of lectures published for older Australian girls.

One of the most popular authors for girls in the first half of the twentieth century, along with Ethel Turner, was Mary Grant Bruce (Lyons \& Taksa 1990, p.89). In the 1910s and 20s, sales of her popular Billlabong series regularly reached over 20,000 copies per book, and David Walker states that Ethel Turner's books sold a similar amount (Walker 1978). Mary Grant Bruce wrote 38 books for children during her life, 15 of which comprised the Billabong series. Bruce has attracted a degree of scholarly interest (see Niall 1979; 1984; Alexander 1979), which has generally attributed her popularity to her realistic yet romantic style of writing, set mostly in the Australian bush. This article will discuss one of Bruce's lesser known works, The Cousin From Town (1923) and compare it with a similar novel written by a less popular author also held in the McLaren collection, Daisy Darvill's The Coming of Chloe: A Story of the Australian Bush (1924). Written ostensibly for younger children, but read mainly by girls, these books take up the popular theme of having a cousin from town or abroad visit family in the Australian bush, where they generally find comfort in the bush folk's hospitality and discover hidden talents such as horse riding, thus winning acceptance from their bush cousins. Brenda Niall observes that this particular storyline 'persisted in various forms for many years...in both the early and the late forms of this kind of novel is the assumption that the real Australia is the bush'. She goes on to say that 'whether the hero (or antihero) comes from London or from Sydney, his ordeal is much the same, and he will need the same qualities of independence, industry and resourcefulness to become a worthy Australian bushman' (Niall 1984, p.27). Although Niall here presumes that 'the cousin from town' is male, this 
discussion will be based around books using a female character for this role. Nevertheless, the premise is the same: that true Australian values are found only in the bush.

Mary Grant Bruce's The Cousin From Town has the young girl Brenda, from Melbourne, coming to visit her uncle and cousins in the country. While most of the family, including a few boy-cousins, accept her almost immediately, it takes longer for her to win appreciation from Mavis, the daughter of the family. When, towards the end of the novel, Mavis falls off her horse and breaks her ankle and Brenda saves her, Brenda finally wins Mavis' respect as well. Bruce's novel, as the title would suggest, is typical of the 'cousin from town' genre. Early on it has Brenda asking her mother how she should act as a 'towny' in the country. Brenda's mother replies, 'the people who don't get on with country folk are those "townies," as you call them, who try to show that they know everything about a farm. Just say plainly that you are ignorant and want to be taught, and you'll find that they will come more than half-way to meet you' (Bruce 1923, p.13). This is typical of the way bush people were portrayed in these novels, as simple folk who were quite happy to teach town folk the ropes if they were not arrogant and over-assuming. As we have seen, Brenda follows the advice of her mother and wins their respect

Darvill's The Coming of Chloe: A Story of the Australian Bush is also targeted at a young audience. Its approach to the 'cousin from town' genre is a little more ham-fisted and much more didactic than Mary Grant Bruce's practised hand shows. This novel has a little girl, Chloe, coming to stay with some family friends in the bush. While Bruce tends to develop her characters through their actions rather than superfluous words, Darvill is forced to explain throughout the text what her characters are thinking. When the Wray boys are told that a small girl is coming to stay, they react accordingly:

"A girl-kid!" Billy repeated, and his voice was full of scorn. "Call a girl coming here very good news? Oh Mum! How could you!” This was too ridiculous. For the very last thing Billy wanted was a silly girl to come and live with them'. The younger boy, however, 'was secretly rather pleased, and he was already hoping that she would like the same sort of things as he did.

(Darvill 1924, p.19)

By the end of the novel, of course, the boys have also come to appreciate the little girl. Despite the fact that this book is set in the Australian bush, Darvill's text lacks the Australian voice present in many Australian girls books of the time. Maurice Saxby says that 'in spite of references to Manly, Rose Bay and Bondi there is little that is genuinely Australian in this thin-blooded piece of Blytonesque holiday fun' (Saxby 1998, p.276). Nevertheless, this book retains the themes of the genre, illustrating again the healing nature of the bush and the hospitality of its people.

Bruce's novel is much better written and plotted than Darvill's, and its characters are more believable. However, the authors of these novels had a similar motive in wanting to portray Australian views and values as coming from the bush. The fact that McLaren acquired two different books of such a similar genre shows a willingness to collect literature of varying quality. While neither of these books would have been considered 'high literature', they would have been read by 
many young Australian girls - and are therefore still of value to the historian interested in creating a representative sample of everything that was read by Australian girls, regardless of quality or status.

McLaren's collection is also rich in books written by English writers but including Australian locations or characters. These books are important to include in a sampling of books read by Australian girls as English literature generally made up the bulk of girls' reading material in the first half of the twentieth century. McLaren included My Cousin From Australia (1894) the by English author Evelyn Everett Green, and That Wild Australian Schoolgirl (1925) by the English author Ethel Talbot for this area of his collection. My Cousin From Australia would have been read not only by girls but also by young Australian women, while Talbot's novel is an example of the English school story genre that was popular throughout the first half of the twentieth century. These novels are particularly interesting for their descriptions of Australians. Indeed, similarities that occur between these characters and the characters of contemporaneous Australian books suggest that these books had a transnational influence on each other.

My Cousin From Australia tells the story of Cicely, an English heiress who is expected to marry a dastardly Englishman, Ferdinand, when she turns of age. When her Australian step-cousin Griffeth comes to stay, she falls in love with him instead and realises she must run away from Ferdinand. In the novel Griffeth is described in glowing terms: 'quite apart from his great height and the magnificent breadth of his chest and shoulders, there was something about the man to arrest attention and win admiration... although his features were irregular and somewhat rugged in outline they were stamped with an individuality that could not fail to arrest attention' (Everett Green 1894, p.34). This was a common way for Australian men to be described at this time: tall, strong and unspoiled by the cosseted English way of life. Later on in the novel it is mentioned that 'Griffeth had never read a line of Rossetti or Swinburne and had the audacity to declare that poetry bored him, that he understood it took a lifetime to appreciate Browning and that for his part he had never "risen above" Shakespeare, whom he could understand' (Everett Green 1894, p.36). Here Everett Green's Australian has no time for the decadent literature of Rossetti and Swinburne, but is still portrayed as being naturally intelligent enough to understand the canonical literature of Shakespeare.

Everett Green's Australian hero is typical of those present in other romance novels of the time; she also appears to use her novel to maintain the contemporary status of women. Kimberley Reynolds says that although Green was aware of the tensions and complexities surrounding women's role at this time, 'she was also attempting to support herself on the proceeds of her writing, and therefore could not afford to alienate publishers, parents and educators [by challenging women's place in society]... her books vigorously embrace and pass on traditional images of masculinity and femininity' (Reynolds 1990, p.118). This agenda is certainly present in My Cousin From Australia, where Griffeth saves Cicely from the clutches of Ferdinand. Griffeth in the novel is an early example of the stereotypical Australian hero, and we see these same stereotypes being used to describe Australians for decades to come, both at home and abroad (see Mary Grant Bruce's Billabong series 1910-1942). Everett Green's novel is a useful example of the types of books that 
older Australian girls would have read, and of the ideas that authors wanted to pass on at this time. Although McLaren included this book in a collection of children's books, it is clearly intended for a slightly older market: the characters are young adults. Kerry M. White says that this type of 'children's book' 'provided an opportunity (for girls) to look into the adult world of love, business, marriage breakdown, childlessness and other concerns that otherwise might have been closed to them' (White 1993, p.78). In this way Australian girls would be presented with ideas of what adult life might look like - although their expectations might have been high if they had only read novels written in the vein of Evelyn Everett Green's.

Ethel Talbot's That Wild Australian Schoolgirl, is written for a slightly younger, school-attending audience but it has similarities to My Cousin From Australia in the way it maintains stereotypes of an Australian character - this time a schoolgirl. The novel embraces the traditional features of an English school story. In Talbot's novel the Australian girl, Peggy, is sent to live with the Dalkeith family in England, who, not knowing what to make of this rather garish Australian personality, send her to a prestigious boarding school for 'finishing'. Peggy is introduced when just off the ship from Australia as a kindly, yet slang-talking girl who has rescued a younger girl without a guardian: “"yes, I bet I'm Margaret; only I'll take it more friendly if you'll call me Peg." The visitor smiled up into Mrs. Dalkeith's face. "And this - well this is a friend of mine. And seeing there wasn't no one on the quay to give her a friendly hail, I've brought her along double quick, in spite of herself", (Talbot 1925, p.12). This is reminiscent of something that Griffeth in My Cousin from Australia might do, as he too rescues strays, wading into a rushing river to rescue a drowning dog. Brenda Niall says that the Australian girl stereotype was a useful one for English school story writers who were looking for original characters, stating that 'colonial frankness and a regrettable accent which make these girls at first unacceptable in their English boarding schools are counter-balanced by exceptional talent for tennis, singing and stopping runaway horses. The Australian girls' democratic ways are a rebuke to English snobbery' (Niall 1984, p.171). This is indeed how the plot runs in Talbot's story.

While the Australian character presented in these novels now seems overdrawn and stereotypical, it would not have seemed out of the ordinary to girl-readers who were used to such fare, and were reading about similar characters in Australian stories. Although neither Everett Green's nor Talbot's books remained long in print, they give us a good idea of the types of books that older Australian girls would have been reading at the beginning of the twentieth century, and show the type of character authors wanted to present girls with. Their presence in McLaren's collection shows that he had a good understanding of the types of novels that older Australian girls were interested in in the first half of the twentieth century.

McLaren also obtained girls' annuals, school books, comics and collections of lectures. One such collection, entitled The House Not Made With Hands: Talks to Older Girls (1942), shows the particular care with which adults educated Australian girls on morality and modesty. Bamford, the wife of a minister, wrote a collection of pieces instructing Australian girls on sexuality. Her text was quite popular, and her 1935 version sold over 10,000 copies and resulted in girls writing to 
Bamford asking for more detailed information. Nevertheless, Bamford's 1942 version, held in the McLaren collection, is still very reserved. Kate Darian-Smith says this is common of the genre, and that in the 1940s 'sex education publications coyly masked all physical details behind moralistic and religious doctrines' (Darian-Smith 2009, p.198) Bamford's text is indeed religious, but it is also peculiarly reductive and not particularly comforting to girls who might have been worrying about their bodies or their sexuality. At one point she states that "the girl who says "I have no time for boys" either is seeking to cover the fact that deep down she has an abundance of time for them, or else she is not normal' (Bamford 1942, p.32). Here the words 'not normal' are coded to mean homosexual. This aspect of sexuality was never mentioned explicitly. Bamford's book is another example of a female author maintaining the status quo for other women: in this instance Bamford tried to control the way Australian girls understood sexuality and femininity. Another example of this is found towards the end of the book in her views of dancing: 'I have seen girls immodestly dressed, clinging to (men) in a dance in a most suggestive and alluring fashion... Such girls either do not know, or do not care, that they are causing undue strain on the man, but on themselves, with whom in the end will rest the responsibility of keeping things in check' (Bamford 1942, pp.33-4). This view of the dangers of dancing with men was a common one in this wartime period, when girls were afforded increased freedom and the possibility of socialising with soldiers.

While we do not know the motivations McLaren had in obtaining particular books for his collection, this collection of lectures is anomalous among a collection that is mostly made up of fiction. Nevertheless, it reminds the scholar that Australian girls were not only presented with social views and values in fictional form, but rather they received life lessons from many different genres of literature.

\section{Conclusion}

Kenneth Kidd states that 'for better and for worse, the children's literature archive seems to represent hope that adults can recover the texts of childhood experience, thereby preserving and understanding childhood itself. Reconstructing the history or histories of childhood through children's materials seems deeply entangled with more personal retrieval or recovery projects' (Kidd 2011, pp.2-3). While these children's books are of great importance as pieces of literature and of history, they dc seem to hold an additional allure for scholars, representing and indeed returning one to that childhood time. The McLaren Collection in the Baillieu Library at the University of Melbourne has a wide array of children's books and associated ephemera associated with the childhoods of many different Australians.

By obtaining books that sit across the spectrum of 'high' and 'low' literature, Ian McLaren has given us an appropriate sample of all of the different sorts of books and ephemera that Australian children would have come across during the twentieth century. However, the apparent lack of focus on girls' books in the collection brings to mind questions over the status of these books at the time of collection and the place of such books in the academic library today. Just as Australian children's books were thought to be considered unworthy of collection, it seems somewhat odd that girls' books have not received an equal amount of attention in the McLaren collection. 
Nevertheless, they represent a small sample of the books that Australian girls would have read, and are of great help to scholars researching in the area of reading history and similar fields. As more scholars come to understand the importance of these books it is clear that they will continue to be used and valued into the foreseeable future.

\section{Endnote}

${ }^{1}$ See the Baldwin Library of Historical Children's Literature at the University of Florida, USA; the Opie Collection at the University of Oxford, UK; International Library of Children's Literature at the Zhejiang Normal University, China.

\section{References}

Alexander, A. (1979) Billabong's Author: The life of Mary Grant Bruce. London, Angus \& Robertson.

Bamford, E.J. (1942) The House Not Made with Hands : Talks to Older Girls. Kyneton, Victoria.

Booth, A. \& Kee, H. The University Gender Gap in Australia: A Long-run Perspective. Available from: http://melbourneinstitute.com/downloads/hilda/Bibliography/Conference_Papers/ Booth_Kee_Gender_Gap.pdf [Accessed 1 April 2012].

Bradford, C. (1998) '(Re)constructing Australian childhood: The Pound Collection at the State Library of Victoria, Australia', The Lion and the Unicorn 22, 3, 327-337.

Bruce, M.G. (1923). The Cousin from Town. Melbourne, Victoria, Whitcombe \& Tombs.

Crosetto, A. \& Horan, M. (2007) 'The Juvenile Collection in the Academic Library', International Journal of the Book 4, 4, 101-107.

Darian-Smith, K. (2009) On the Home Front : Melbourne in Wartime : 1939-1945, 2nd ed. Carlton, Victoria, MUP.

Darvill, D. (1924) The Coming of Chloe : A Story of the Australian Bush. London, Religious Tract Society.

'Enrolment Rates in Secondary Schools, 1925-2005' Available from: http://www.governmentschools.det.nsw.edu.au/files/enrolment_rates.pdf [Accessed 2 April 2012].

Everett Green, E. (1894) My Cousin From Australia. London, Hutchinson \& Col.

Kidd, K. (2011) 'The child, the scholar, and the children's literature archive', The Lion and the Unicorn 35, 1, 1-23.

Lyons Clark, B. (2003) Kiddie Lit: The Cultural Construction of Children's Literature in America. Baltimore, The Johns Hopkins University Press.

Lyons, M. \& Taksa, L. (1992). Australian Readers Remember: An Oral History of Reading 18901930. Melbourne, OUP.

Morris, P.A. 'Preservation needs of children's literature in academic libraries', Portal: Libraries and the Academy 10, 1, 95-110.

'McLaren Collection' National Library of Australia. Available from: http://www.nla.gov.au/selected-library-collections/mclaren-collection [Accessed 1 March 2012]. 
Niall, B. (1979) Seven Little Billabongs: The World of Ethel Turner and Mary Grant Bruce. Carlton, Victoria, Melbourne University Press.

Niall, B. (1984) Australia Through the Looking Glass: Children's Fiction 1830-1980. Carlton, Victoria, Melbourne University Press.

O’Neil, T.O. (1994) 'Confessions of a literary sleuth', The University of Melbourne Library Journal 1, 4, 6-9.

Paris, M. (2004) Over the Top: The Great War and Juvenile Literature in Britain. Westport, Conn., Praeger.

Reynolds, K. (1990) Girls Only? Gender and Popular Children's Fiction in Britain, 1880-1910. New York, Harvester/Wheatsheaf.

Saxby, M. (1998) Offered to Children: A History of Australian Children's Literature 1841-1941. Sydney, Scholastic.

Scott, W.J. (1981) Reading, Film and Radio Tastes of High School Boys \& Girls. Ann Arbor, Mich., University Microfilms International.

Talbot, E. (1925) That Wild Australian School-Girl. London, Robert South, Ltd.

University of Melbourne. (1999) Children's Books 3 Bibliographies of Collections at the University of Melbourne Library. Parkville, Victoria, University of Melbourne Library.

Walker, D. (1978) 'War, women and the bush: The novels of Mary Grant Bruce and Ethel Turner', Historical Studies 18, 71, 297-315.

White, K. (1993) 'The real Australian girl? Some post-federation writers for girls', in K. Ferres (ed) The Time to Write: Australian Women Writers 1890-1930. Penguin, Australia, pp.73-87.

\section{SOCR}

\section{Biographical Note}

Bronwyn Lowe is a $\mathrm{PhD}$ candidate in the School of Historical and Philosophical Studies at the University of Melbourne. She is writing a thesis on Australian girls' reading practices in the first half of the twentieth century. She recently had an article based on her honours thesis published in the Melbourne Historical Journal entitled 'Reflections of Gender and Memory: Personal Experiences of Women of the WAAAF during the Second World War'. 